\title{
First report of Sclerotinia sclerotiorum causing white rot of marigold in Punjab, India
}

\author{
Pankaj Kumar $^{1}$ (D) Shikha Sharma ${ }^{2} \cdot$ Ranjit Singh $^{1} \cdot$ Parminder Singh $^{1} \cdot$ Ankush Kumar $^{3}$
}

Received: 26 July 2021 / Accepted: 19 October 2021 / Published online: 29 October 2021

(c) Società Italiana di Patologia Vegetale (S.I.Pa.V.) 2021

Keywords Marigold $\cdot$ Sclerotinia sclerotiorum $\cdot$ Tagetes erecta $\cdot$ White rot

Marigold (Tagetes L.) is widely cultivated in Indian subcontinent for loose flower production year-round. Flowers of African marigold (T. erecta L.) cv. Punjab Gainda No 1 grown at Punjab Agricultural University, Ludhiana, were covered with white cottony mycelial growth and showed white mould rot symptoms in January, 2021, which had 30\% disease incidence. Numerous dark brown to black fungal sclerotia were found embedded in hollow peduncle. Matured sclerotia (15.70), elliptical to irregular, ranging from 5 to $10 \mathrm{~mm}$ (diameter) were observed along the margins after 7 days on PDA. Molecular characterization of the fungus was done on basis of internal transcribed spacer (ITS-rDNA) region via using primer pair ITS1/ITS4. BLAST analysis of sequence (Accession No. MW877786) showed that isolate shared close nucleotide (nt) identity i.e., $99.42 \%$ with S. sclerotiorum isolates (MK757685.1, MH333282.1 and KJ522780.1). To confirm the pathogenicity, macerated mycelial mat was sprayed on 20 plants of T. erecta and $T$. patula. Water sprayed plants were treated as control. After 7 days of inoculation, all floral buds of inoculated plants showed the white mould rot symptoms, whereas the uninoculated plants remained healthy. Pathogen was re-isolated and morphological traits were found to be similar with inoculated culture. In India, white mould rot of marigold is well established and was reported to be caused by Sclerotium rolfsii (Rout et al. 2015; Gurjar et al. 2019). Association of S. sclerotiorum, as casual agent of white rot on

Pankaj Kumar

pankajbodla@pau.edu

1 Department of Floriculture and Landscaping, Punjab Agricultural University, Ludhiana, India

2 Department of Plant Pathology, Punjab Agricultural University, Ludhiana, India

3 Department of Plant Pathology, CCS Haryana Agricultural University, Hisar, India
African marigold from Uttar Pradesh, India, is also reported but pathogen was identified only on basis of morphological characteristics (Singh et al. 1998). Hence, to the best of our knowledge, this is the first molecular evidence of association of S. sclerotiorum (Lib) de Bary in causation of white rot disease of marigold from Punjab, India.

Acknowledgement Authors acknowledge the help rendered by Head, Department of Floriculture and Landscaping, Punjab Agricultural University for providing funds and necessary facilities for the research work.

Data availability rDNA ITS region sequencing of the pathogen is openly available in the NCBI GenBank Database.

\section{Declarations}

Conflict of interest The authors declare that they have no conflicts of interest associated with this publication.

\section{References}

Gurjar P, Meena L, Verma AK (2019) Diseases of marigold (Tagetes erecta) and their management: a review. Int J Adv Sci Res 4(4):137-144

Rout MK, Mohant P, Dash SR, Parida D (2015) Studies on effect of $\mathrm{pH}$, temperature and relative humidity on growth and sporulation of Alternaria alternata and Sclerotium rolfsii causing bud rot and collar rot in marigold. Trends Biosci 8(24):6785-6787

Singh HB, Kalra A, Patra NK, Kumar S (1998) African marigold a new host of Sclerotinia sclerotiorum. J Mycol Plant Pathol 28(3):365-366

Publisher's Note Springer Nature remains neutral with regard to jurisdictional claims in published maps and institutional affiliations. 